\title{
A quantitative real time PCR method to analyze $T$ cell receptor $V \beta$ subgroup expansion by staphylococcal superantigens
}

\author{
Keun Seok Seo ${ }^{1}$, Joo Youn Park², David S Terman³, Gregory A Bohach ${ }^{1 *}$
}

\begin{abstract}
Background: Staphylococcal enterotoxins (SES), SE-like (SEl) toxins, and toxic shock syndrome toxin-1 (TSST-1), produced by Staphylococcus aureus, belong to the subgroup of microbial superantigens (SAgs). SAgs induce clonal proliferation of T cells bearing specific variable regions of the T cell receptor $\beta$ chain $(V \beta)$. Quantitative real time PCR (qRT-PCR) has become widely accepted for rapid and reproducible mRNA quantification. Although the quantification of $V \beta$ subgroups using $q R T-P C R$ has been reported, qRT-PCR using both primers annealing to selected V $\beta$ nucleotide sequences and SYBR Green I reporter has not been applied to assess V $\beta$-dependent expansion of T cells by SAgs.

Methods: Human peripheral blood mononuclear cells were stimulated with various SAgs or a monoclonal antibody specific to human CD3. Highly specific expansion of V $\beta$ subgroups was assessed by qRT-PCR using SYBR Green I reporter and primers corresponding to selected $\vee \beta$ nucleotide sequences.

Results: qRT-PCR specificities were confirmed by sequencing amplified PCR products and melting curve analysis. To assess QRT-PCR efficiencies, standard curves were generated for each primer set. The average slope and $R^{2}$ of standard curves were $-3.3764 \pm 0.0245$ and $0.99856 \pm 0.000478$, respectively, demonstrating that the qRT-PCR established in this study is highly efficient. With some exceptions, SAg VB specificities observed in this study were similar to those reported in previous studies.

Conclusions: The qRT-PCR method established in this study produced an accurate and reproducible assessment of $\vee \beta$-dependent expansion of human T cells by staphylococcal SAgs. This method could be a useful tool in the characterization T cell proliferation by newly discovered SAg and in the investigation of biological effects of SAgs linked to pathogenesis.
\end{abstract}

\section{Background}

The $\alpha / \beta$ T cell receptor (TCR) is composed of $\alpha$ and $\beta$ chain heterodimers which recognize antigen-derived peptide bound to major histocompatibility complex (MHC) molecules on antigen presenting cells (APCs) [1]. During thymocyte development, the genes encoding the $\beta$ chain undergo somatic recombination of variable $(\mathrm{V})$, diversity $(\mathrm{D})$, joining $(\mathrm{J})$, and constant $(\mathrm{C})$ genes. Combinatorial joining of $\mathrm{V}-\mathrm{J}$ and $\mathrm{V}-\mathrm{D}-\mathrm{J}$ region gene segments generates diversity within the TCR $\beta$ chain complementarity determining region (CDR) 3 loop $[2,3]$.

\footnotetext{
* Correspondence: gbohach@uidaho.eud

* Correspondence: gbohach@uidaho.eud of Idaho, Moscow, ID 83844, USA
} (1)

(c) 2010 Seo et al; licensee BioMed Central Ltd. This is an Open Access article distributed under the terms of the Creative Commons Attribution License (http://creativecommons.org/licenses/by/2.0), which permits unrestricted use, distribution, and reproduction in any medium, provided the original work is properly cited.

Combinatorial diversity is further increased by imprecise joining of VDJ recombination and insertion of palindromic nucleotides at a specific point within the VD, DJ, and VJ junctions [4]. As a result, each $\mathrm{T}$ cell clone expresses a unique variable region of TCR $\beta$ chain $(\mathrm{V} \beta)$ [5]. Generally, the CDR1 and CDR2 sequences within the TCR molecule, encoded by V gene segments, interact with the $\alpha$ helix of the MHC molecule [6]. TCR CDR3 sequences, encoded by V(D)J junction gene segments, interact with the antigenic peptide associated with MHC, resulting in clonal T cell proliferation [6].

Staphylococcal enterotoxins (SEs), SE-like (SEl) toxins and toxic shock syndrome toxin-1 (TSST-1), produced by Staphylococcus aureus, are prototypic microbial superantigens (SAgs). Members of this toxin subgroup 
are implicated in staphylococcal food poisoning and toxic shock syndrome [7]. SEl toxins have been shown to lack emetic properties in primates or have not yet been tested [8]. For many years, five antigenically distinct classic SEs (SEA, SEB, SEC, SED, and SEE) and molecular variants of SEC (SEC1, SEC2, and SEC3) were recognized [7]. Through improvements in genomic analysis tools, novel SEs and SEl toxins including SEG, SElH, SEI, SEIJ, SElK, SElL, SElM, SElO, SEIP, SElQ, SEIR, and SEIU and four molecular variants (SEGv, SEIv, SEINv, and SEIUv) have been discovered $[7,9]$. In contrast to conventional antigens, most SAgs bind outside the peptide binding groove of MHC II, and to specific $\mathrm{V} \beta$ sequences [9]. This interaction triggers an activation of phospholipase $\mathrm{C}$ and phosphokinase $\mathrm{C}$ pathways [10], leading to a massive production of proinflammatory cytokines including interleukin-2 and interferon- $\gamma[11]$, resulting in extensive proliferation of $\mathrm{T}$ cells bearing specific V $\beta$ subgroups [11]. As a result, it is possible to characterize SAgs on the basis of their $\mathrm{V} \beta$ profiles [7].

Several approaches are used to quantify the expansion of $V \beta$ subgroups including northern blotting, semiquantitative PCR using radioisotope conjugated probes [12], or fluorescence activated cell sorting (FACS) using monoclonal antibodies (mAbs) specific to $\mathrm{V} \beta$ subgroups $[13,14]$. Recently, quantitative real time PCR (qRT-PCR) has become widely accepted for rapid and reproducible quantification of gene expression. Most previous attempts to quantify V $\beta$ expression using qRT-PCR used one primer located at the gene encoding TCR constant region of $\beta$ chain $(C \beta)$ and the other primer or fluorogenic probe located within the gene encoding the $\mathrm{V}$ region $[15,16]$. More importantly, previous qRT-PCR methods have been applied to samples displaying expansion of limited numbers of V $\beta$ subgroups [16]. In this study, we developed a new qRT-PCR method using V $\beta$ subgroup specific primers within the gene encoding the $\mathrm{V}$ region to increase specificity and SYBR Green I to curtail the cost of the assay. This technique was applied to human mononuclear cell cultures stimulated with various SAgs, which have unique $V \beta$ specificities, though overlapping so that the entire repertoire of $\mathrm{V} \beta$ subgroups could be evaluated using this method.

\section{Materials and methods \\ Toxin production and purification}

SEB, SEC1 and TSST-1 were purified from cultures of $S$. aureus MNHOCH, S. aureus RN4220 (pMIN121) and $S$. aureus RN4220 (pCE107), respectively, using preparative isoelectric focusing as described previously [17-19]. Other toxins used in this study were produced in recombinant form using SE genes cloned in this study as follows. A DNA fragment encoding SEA, SED, SEE, SEG, SEI, SEIM, SEIN, or SElO was amplified from genomic DNA derived from S. aureus FRI 913 or FRI 472 using primers listed in Table 1[20]. Amplified DNA fragments were digested with $\mathrm{NdeI}$ and BamHI or XhoI and ligated into corresponding sites is pET-15b (Novagen, San Diego, California, USA). Recombinant SE proteins were expressed in E. coli BL21 (DE3) (pLysS) and purified using the His-Bind Purification Kit (Novagen) as suggested by the manufacturer.

\section{Preparation and stimulation of enriched human lymphocytes}

Peripheral blood mononuclear cells (PBMCs) were isolated from three healthy donor venous blood. Heparintreated $(14 \mathrm{U} / \mathrm{ml}$ blood) blood was fractionated by gradient centrifugation over Ficoll-Paque Plus (GE Healthcare, Piscataway, New jersey, USA) as described previously [17]. The PBMCs were washed and resuspended in RPMI 1640 medium (Life technologies, Gaithersburg, Maryland, USA) supplemented with 2\% FBS, $100 \mathrm{U}$ penicillin $\mathrm{G}$, and $100 \mu \mathrm{g} / \mathrm{ml}$ streptomycin. The cultures were maintained in cell culture Petri dishes (Falcon, Lincoln Park, New Jersey) overnight at $37^{\circ} \mathrm{C}$ and in $5 \% \mathrm{CO}_{2}$. Non-adherent lymphocyte-enriched PBMCs were collected, washed, and resuspended at a final concentration of $2.5 \times 10^{6}$ cells $/ \mathrm{ml}$. Each SAg $(0.5$ $\mu \mathrm{g} / \mathrm{ml}$ ) or a murine $\mathrm{mAb}$ specific to human CD3 (33 ng/ml; Sigma, St. Louis, Missouri, USA) was added to lymphocyte enriched PBMC cultures ( $3 \mathrm{ml}$ aliquots). Cultures were maintained for 4 days $\left(37^{\circ} \mathrm{C}, 5 \% \mathrm{CO}_{2}\right)$.

Table 1 List of primers used to clone SE and SEI genes.

\begin{tabular}{|c|c|c|c|}
\hline SE name & GenBank access number & Forward primer ('5 to 3 ') & Reverse primer ('5 to 3 ') \\
\hline SEA & M18970 & cttgtacatatgagcgagaaaagcgaagaa & gcgcggatccttaacttgtatataaata \\
\hline SED & M28521 & cgttctcgagaatgaaaacattgattc & cgcgctcgagctacttttcatataaata \\
\hline SEE & M21319 & ggtagccatatgagcgaagaaataaatgaa & gcgcggatcctcaagttgtgtataaata \\
\hline SEG & AF064773 & tgtgcatatgcaacccgatcctaaatta & gcgcggatcctcagtgagtattaaga \\
\hline SEl & AF285760 & tgctctcgaggatattggtgtaggtaac & cgcgctcgagttagttactatctacata \\
\hline SEIM & AF285760 & cgcacatatggatgtcggagttttgaat & gcgcggatcctcaactttcgtccttata \\
\hline SEIN & AF285760 & aatgctcatatggacaaaaaagatttaaag & gcgcggatccttaatctttatataaaa \\
\hline SEIO & AF285760 & tgcactcgagaatgaagaagatcctaaa & cgcgctcgagttatgtaaataaataaac \\
\hline
\end{tabular}


Basal levels of V $\beta$ expansion were assessed with unstimulated control cultures.

\section{Quantitative RT-PCR (qRT-PCR)}

Total RNA was extracted from approximately $5 \times 10^{6}$ cells using Trizol (Life Technologies). Superscript II reverse transcriptase (Life Technologies) was used to generate cDNA using $1 \mu \mathrm{g}$ of RNA and oligo dT primer, according to the manufacturer's instructions. To promote highly specific amplification, two primers specific for each of the various $V \beta$ subgroups were annealed to selected V $\beta$ nucleotide sequences. All V $\beta$ specific and $C \beta$ primers were designed using Primer Express version 2.0 (Applied Biosystems, Foster City, California, USA) and are listed in Table 2. We used the $\mathrm{V} \beta$ subgroup nomenclature of Arden et al [21].

To verify primer specificities, melting curve analyses (below) and PCR product sequencing were performed. For sequencing, PCR reactions were conducted without SYBR Green I using cDNA generated from cultures stimulated CD3-specific mAb. PCR products were purified using a PCR purification kit (Qiagen, Valencia, California, USA) and then cloned into pCR2.1 vector (Life Technologies). Transformants (10 to 25 colonies) were randomly selected and the cloned gene fragments were sequenced using an ABI Prism 3100 Genetic Analyzer (Applied Biosystems).

Standard curves were generated for each gene to evaluate primer efficiency and for data analysis. Concentrations of purified PCR products were determined by measuring the absorbance at $260 \mathrm{~nm}$ using a Nanodrop (Thermo Scientific, Wilmington, Delaware, USA) and expressed as the number of DNA copies/ml using standard procedures $[22,23]$. The qRT-PCR was performed (below) on serially diluted PCR products $\left(2.5-2.5 \times 10^{5}\right.$ copies/reaction) using ABI Prism 7500 (Applied Biosystems) in triplicate and was repeated in at least three separate experiments. Standard curves were generated by plotting the $C_{T}$ vs. the $\log _{10}$ copies of serially diluted PCR products. The slope, intercept, and correlation coefficient $\left(R^{2}\right)$ were determined by linear regression analysis using Microcal OriginPro Version 7.5 (OriginLab, Northampton, Massachusetts, USA).

The qRT-PCR was performed in triplicate and was repeated in at least three separate experiments using the following conditions. Reaction mixtures contained $12.5 \mu \mathrm{l}$ of SYBR Green I dye master mix (Applied Biosystems), 2 pmoles each of forward and reverse

Table 2 List of qRT-PCR primersa and amplified V $\beta$ gene(s).

\begin{tabular}{|c|c|c|c|c|}
\hline Primer name & GenBank access number & Forward primer ('5 to $\left.3^{\prime}\right)$ & Reverse primer ('5 to $\left.3^{\prime}\right)$ & Amplified V $\beta$ gene $(s)^{b}$ \\
\hline$C \beta$ & L36092 & tccagttctacgggetctcg & gacgatctgggtgacgggt & \\
\hline VB1 & L36092 & ggagcaggcccagtggat & cgctgtccagttgctggtat & TCRVB1s1 \\
\hline VB2 & M11955 & gagtctcatgctgatggcaact & tctcgacgccttgctcgtat & TCRVB2s1 \\
\hline VB3 & U08314 & tcctctgtcgtgtggccttt & tctcgagctctgggttactttca & TCRVB3s1 \\
\hline VB4 & L36092 & ggctctgaggccacatatgag & ttaggtttgggcggctgat & TCRVB4s1 \\
\hline VB5 & L36092 & gctccaggctgctctgttg & tttgagtgactccagcctttactg & TCRVB5s1, 5s3 \\
\hline VB6 & X61440 & ggcagggeccagagtttc & gggcagecctgagtcatct & TCRVB6s1, 6s2, 6s3, 6s4, 6s5, 6s6 \\
\hline VB7 & U07977 & aagtgtgccaagtcgcttctc & tgcagggcgtgtaggtgaa & TCRVB7s1, 7s2, 7s3 \\
\hline VB8 & X07192 & tgcccgaggatcgattctc & tctgagggctggatcttcaga & TCRVB8s1, 8s2, 8s3 \\
\hline VB9 & U07977 & tgcccgaggatcgattctc & tctgagggctggatcttcaga & TCRVB9s1 \\
\hline VB11 & L36092 & catctaccagaccccaagatacct & atggeccatggtttgagaac & TCRVB11s1 \\
\hline VB12 & U03115 & gttcttctatgtggecctttgtct & tcttgggctctgggtgattc & TCRVB12s1, 12s3 \\
\hline VB13A & L36092 & tggtgctggtatcactgaccaa & ggaaatcctctgtggttgatctg & TCRVB13s1, 13s6 \\
\hline VB13B & X61445 & tgtgggcaggtccagtga & tgtcttcaggacccggaatt & TCRVB13s2, $13 s 9$ \\
\hline VB14 & L36092 & gctccttggctatgtggtcc & ttgggttctgggtcacttgg & TCRVB14s1 \\
\hline VB15 & M11951 & tgttacccagaccccaagga & tgacccttagtctgagaacattcca & TCRVB15s1 \\
\hline VB16 & X06154 & cggtatgcccaacaatcgat & caggctgcaccttcagagtaga & TCRVB16s1 \\
\hline VB17 & U48260 & caaccaggtgctctgctgtgt & gactgagtgattccaccatcca & TCRVB17s1 \\
\hline VB18 & L36092 & ggaatgccaaaggaacgattt & tgctggatcctcaggatgct & TCRVB18s1 \\
\hline VB20 & L36092 & aggtgccccagaatctctca & ggagcttcttagaactcaggatgaa & TCRVB20s1 \\
\hline VB21 & M33233 & gctgtggctttttggtgtga & caggatctgccggtaccagta & TCRVB21s1 \\
\hline VB22 & L36092 & tgaaagcaggactcacagaacct & tcacttcctgtcccatctgtgt & TCRVB22s1 \\
\hline VB23 & U03115 & ttcagtggctgctggagtca & cagagtggctgtttccctcttt & TCRVB23s1 \\
\hline VB24 & U03115 & acccctgataacttccaatcca & cctggtgagcggatgtcaa & TCRVB24s1 \\
\hline
\end{tabular}

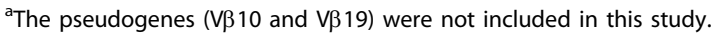

${ }^{\mathrm{b}} \mathrm{V} \beta$ subgroup nomenclature followed the classification of Arden et al. [21]. 
primers, and $5 \mu \mathrm{l}$ of 100 times diluted cDNA. Thermocycle conditions included initial denaturation at $50^{\circ} \mathrm{C}$ and $95^{\circ} \mathrm{C}(10 \mathrm{~min}$ each $)$, followed by 40 cycles at $95^{\circ} \mathrm{C}$ $(15 \mathrm{~s})$ and $60^{\circ} \mathrm{C}(1 \mathrm{~min})$. Fluorescent data were acquired during each extension phase. After 40 cycles, a melting curve was generated by slowly increasing $\left(0.1^{\circ} \mathrm{C} / \mathrm{s}\right)$ the temperature from $60^{\circ} \mathrm{C}$ to $95^{\circ} \mathrm{C}$, while the fluorescence was measured. The threshold cycle $\left(\mathrm{C}_{\mathrm{T}}\right)$ was calculated using the Sequence Detector Systems version 1.2.2 (Applied Biosystems) by determining the cycle number at which the change in the fluorescence of the reporter dye $(\Delta \mathrm{Rn})$ crossed the threshold. To synchronize each experiment, the baseline was set automatically by the software. To rule out DNA contamination in the RNA preparations, the qRT-PCR controls were performed with RNA templates which did not show any amplification.

\section{Data analysis}

Calculations to determine the extent of $\mathrm{V} \beta$ expansion were done as described by calculating the absolute copy number of each $V \beta$ and $C \beta$. Briefly, the $C_{T}$ for each $V \beta$ and $C \beta$ was converted into absolute copy number by extrapolation from its standard curve (above). The percentage of each $\mathrm{V} \beta(\% \mathrm{~V} \beta)$ in the culture was calculated by following equation, where $n$ represents each $V \beta$ subgroup observed in this study. These values have to be considered as exploratory:

$$
\% V \beta_{n}=\left(\frac{V \beta_{n}}{C \beta}\right) \times 100
$$

Selective expansion of $\mathrm{V} \beta \mathrm{s}$ in the culture stimulated with SAgs was determined when each $\% \mathrm{~V} \beta$ from the cultures stimulated with SAgs was significantly higher than the corresponding \%V $\beta$ from the control cultures (without stimuli) by paired $t$-test $(\mathrm{p}<0.001)$ using SAS statistical software (version 9.0, SAS Institute Inc., Cary, North Carolina, USA).

\section{Results}

\section{Sensitivity and efficiency of the qRT-PCR}

cDNA was generated from cultures stimulated with a CD3-specific $\mathrm{mAb}$, amplified by PCR using primers specific for $\mathrm{V} \beta, \mathrm{C} \beta$, and G3PDH genes. Standard curves were generated using the purified PCR products. Representative results from a $C \beta$ primer-based reaction are shown in Figure 1A. The qRT-PCR could detect $\leq 25$ copies of $C \beta$ PCR products without detectable variation among triplicate reactions (Figure 1A). The slope and correlation coefficient $\left(\mathrm{R}^{2}\right)$ of standard curves are used to determine primer efficiency and standard curve validity, respectively. Results obtained with the $C \beta$ reaction are representative data showing the slope for $C \beta$ reaction was -3.38 with $R^{2}$ value of 0.9986 (Figure $1 B$ ). The slope and $R^{2}$ value of standard curves for other reactions are listed in Table 3.

\section{Specificity of the qRT-PCR}

qRT-PCR specificities were assessed by melting curve analysis and sequencing of amplified PCR products. Melting curves of the qRT-PCR reactions observed for $\mathrm{V} \beta$ subgroups consisting of a single gene, as well as G3PDH and $C \beta$ genes, showed single peak. A representative result obtained for $\mathrm{V} \beta 1$ is shown in Figure 1C. The melting curve for the $V \beta 1$ reaction contained a single peak at $78^{\circ} \mathrm{C}$. Melting curves for $\mathrm{V} \beta$ subgroups consisting of multiple subgroup genes $(\mathrm{V} \beta 7,12,13 \mathrm{~A}$, and 17) showed multiple peaks due to the expected heterogeneity in amplified gene fragments. Representative results for V $\beta 17$ are shown in Figure 1D. qRT-PCR for $\mathrm{V} \beta 17$, which contains three subgroup genes produced a melting curve with three peaks as expected. However, some $\mathrm{V} \beta$ subgroups consisting of multiple subgroup genes $(\mathrm{V} \beta 5,6,8,13 \mathrm{~B}$, and 21$)$ showed only a single peak (data not shown). To identify whether primers designed for these V $\beta$ subgroups amplified the targeted subgroup genes, PCR products were cloned and sequenced. This revealed that, except for V $\beta 21$, the primers amplified multiple $\mathrm{V} \beta$ subgroup genes within the targeted V $\beta$ subgroup (Table 2). No untargeted sequences were generated. We also analyzed the amplified PCR products using agarose gel electrophoresis and confirmed that there was no non-specific amplification other than expected size of amplification product (data not shown).

\section{Quantification of $\mathrm{V} \beta$ expansion}

To assess the basal expression level, the percentage of each V $\beta(\% \mathrm{~V} \beta)$ in cultures without stimuli was calculated (Figure 2; unstimulated panel). Similarly, the expression of each $\mathrm{V} \beta$ subgroup gene was determined for cultures stimulated with anti-CD3 $\mathrm{mAb}$ or various SAgs. Selective expansion of $T$ cells bearing certain $V \beta$ subgroups was considered to be significant when the \% $\mathrm{V} \beta$ in the stimulated cultures was elevated at a statistically significant level $(\mathrm{p}<0.05)$. There was no significant difference among levels observed in cultures stimulated with the anti-CD3 $\mathrm{mAb}$ and unstimulated cultures (Figure 2). In contrast, the pattern of $\mathrm{V} \beta$ expression in cultures stimulated with various SAgs showed a distinct expansion of $\mathrm{T}$ cells bearing certain $\mathrm{V} \beta$ subgroups (Figures 3, Table 4). The data indicate that each V $\beta$ subgroup was expanded by one or more SAgs used in this study. As shown in Table 4, the VB specificities of SAgs observed in this study were very similar to those described in previous studies with minor variation as discussed below $[7,11,12,24-26]$. 


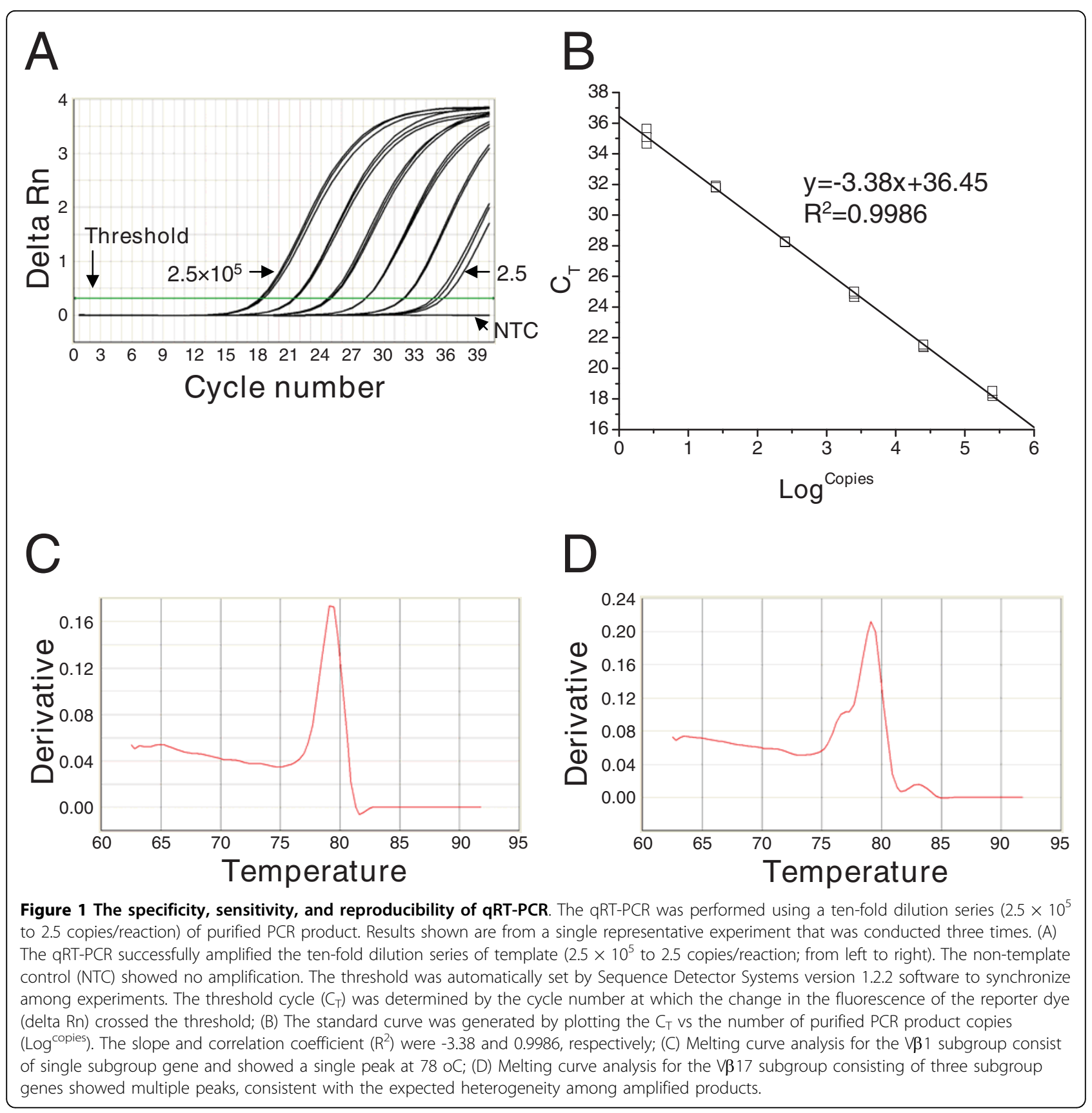

\section{Discussion}

More than 67 different human $V \beta$ genes, of which a quarter are pseudogenes, have been have been cloned and sequenced $[2,21,27]$. These studies confirmed the existence of 49 functional $V \beta$ genes within 24 different $\mathrm{V} \beta$ subgroups. Due to the heterogeneity, some of the 24 $\mathrm{V} \beta$ subgroups consist of multiple subgroup genes. In this study, we designed two primers annealing to each of 22 different $V \beta$ subgroups (36 V $\beta$ genes) to quantify expansion of $\mathrm{T}$ cell bearing specific $\mathrm{V} \beta$ subgroups and subgroup genes in response to SAgs.
One of the important factors that affect the validity of qRT-PCR is the efficiency of primers. The primers used in qRT-PCR should have uniform and high efficiency to achieve a valid quantification. The efficiency and linearity of primers could be assessed by analyzing the slope and $R^{2}$ value of the standard curve, respectively. In theory, the slope should be close to -3.32 with an optimal efficiency when 10 -fold serially diluted templates were used. The average slope and $R^{2}$ of standard curves for all primers used in qRT-PCR was $-3.3764 \pm 0.0245$ and $0.99856 \pm 0.000478$, respectively. This suggests that all 
Table 3 Standard curve slopes, $Y$ axis intercepts and correlation coefficients $\left(\mathbf{R}^{2}\right)$

\begin{tabular}{lccc}
\hline Primers & Slope & Y axis intercept & Correlation coefficient $\mathbf{( R}^{\mathbf{2}} \mathbf{~}$ \\
\hline C 3 & -3.38 & 36.45 & 0.9986 \\
VB1 & -3.39 & 36.54 & 0.9977 \\
VB2 & -3.36 & 36.38 & 0.9982 \\
VB3 & -3.41 & 36.57 & 0.9987 \\
VB4 & -3.37 & 36.62 & 0.9984 \\
VB5 & -3.35 & 36.33 & 0.9976 \\
VB6 & -3.40 & 36.53 & 0.9978 \\
VB7 & -3.36 & 36.43 & 0.9983 \\
VB8 & -3.37 & 36.40 & 0.9986 \\
VB9 & -3.38 & 36.49 & 0.9985 \\
VB11 & -3.41 & 36.52 & 0.9986 \\
VB12 & -3.42 & 36.53 & 0.9972 \\
VB13A & -3.34 & 36.34 & 0.9978 \\
VB13B & -3.41 & 36.54 & 0.9974 \\
VB14 & -3.36 & 36.33 & 0.9981 \\
VB15 & -3.35 & 36.44 & 0.9976 \\
VB16 & -3.37 & 36.44 & 0.9984 \\
VB17 & -3.39 & 36.53 & 0.9982 \\
VB18 & -3.35 & 36.44 & 0.9986 \\
VB20 & -3.33 & 36.39 & 0.9973 \\
VB21 & -3.36 & 36.38 & 0.9986 \\
VB22 & -3.39 & 36.47 & 0.9981 \\
VB23 & -3.37 & 36.43 & 0.9980 \\
VB24 & -3.41 & 36.53 & 0.9984 \\
\hline & & &
\end{tabular}

primers used in qRT-PCR have uniform and high efficiency and linearity.

The specificity of qRT-PCR using SYBR Green I platform was often determined by analyzing melting curves. In this study, the specificities of each primer set were determined by analyzing melting curves and sequencing amplified PCR products. Melting curve analysis and sequencing amplified PCR products of reactions for, $C \beta$ and $V \beta$ subgroups consisting of a single subgroup showed a single peak and a single specific amplification. As expected, some $\mathrm{V} \beta$ subgroups comprised of multiple subgroup genes (VB7, 12, 13A, and 17) showed a corresponding number of peaks. However, some V $\beta$ subgroups comprised of multiple subgroup genes (V $\beta 5,6$, $8,13 \mathrm{~B}$, and 21) showed only a single peak. The sequence analysis of amplified PCR products for $\mathrm{V} \beta 5,6$, $8,13 \mathrm{~B}$, and 21 subgroups revealed that multiple subgroup genes were amplified. For example, the V $\beta 6$ subgroup, consisting of 6 functional subgroup genes with > $87.9 \%$ sequence similarity to each other, showed a single peak in melting curve analysis, though the sequence analysis of amplified PCR product showed that all 6 functional subgroup genes were amplified. The resolution of these into a single peak probably due to a high level nucleotide sequence similarity among subgroup genes resulting in an identical meting temperature of amplified gene fragments. The identity of all sequenced PCR products matched with corresponding subgroups

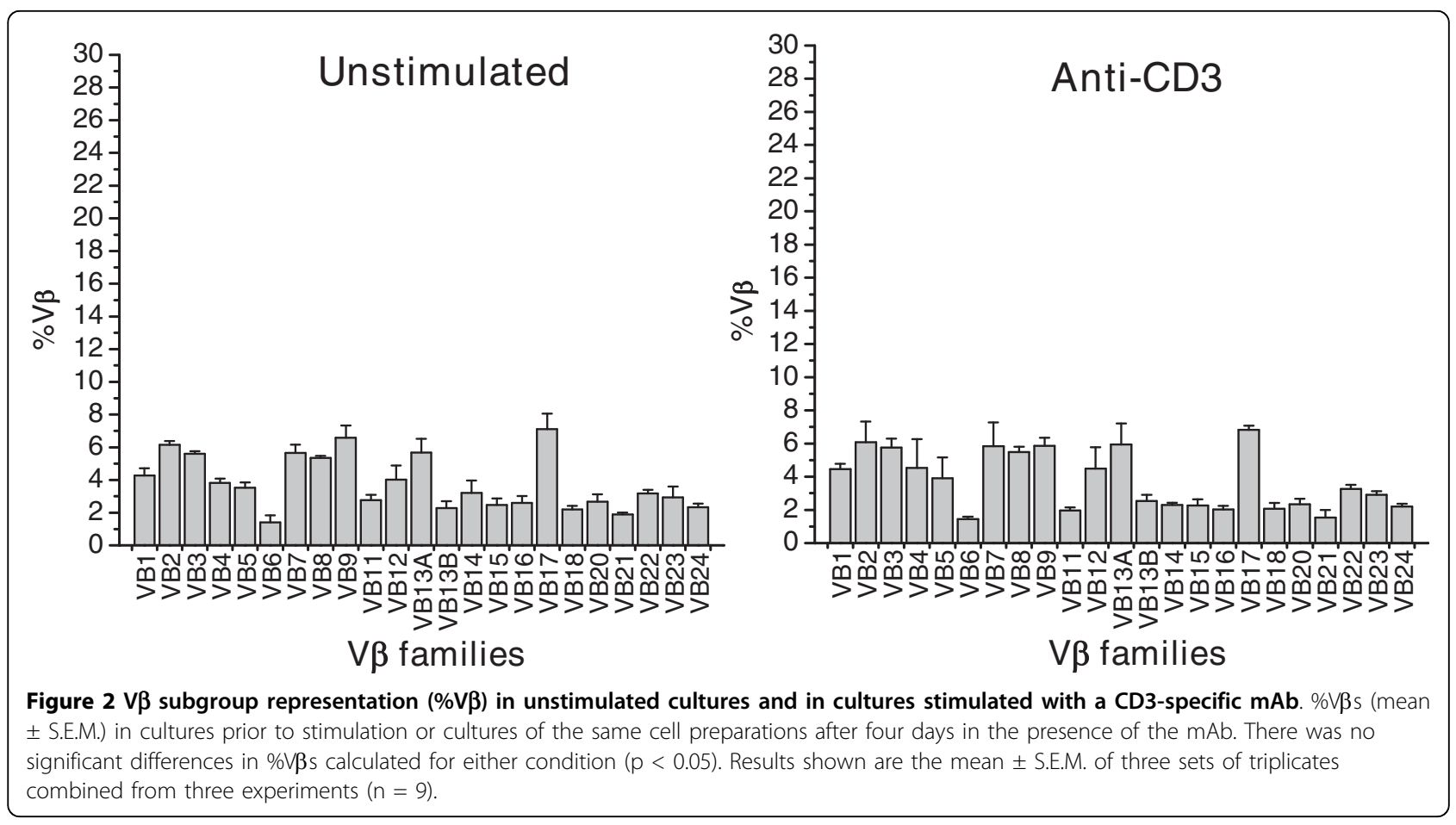




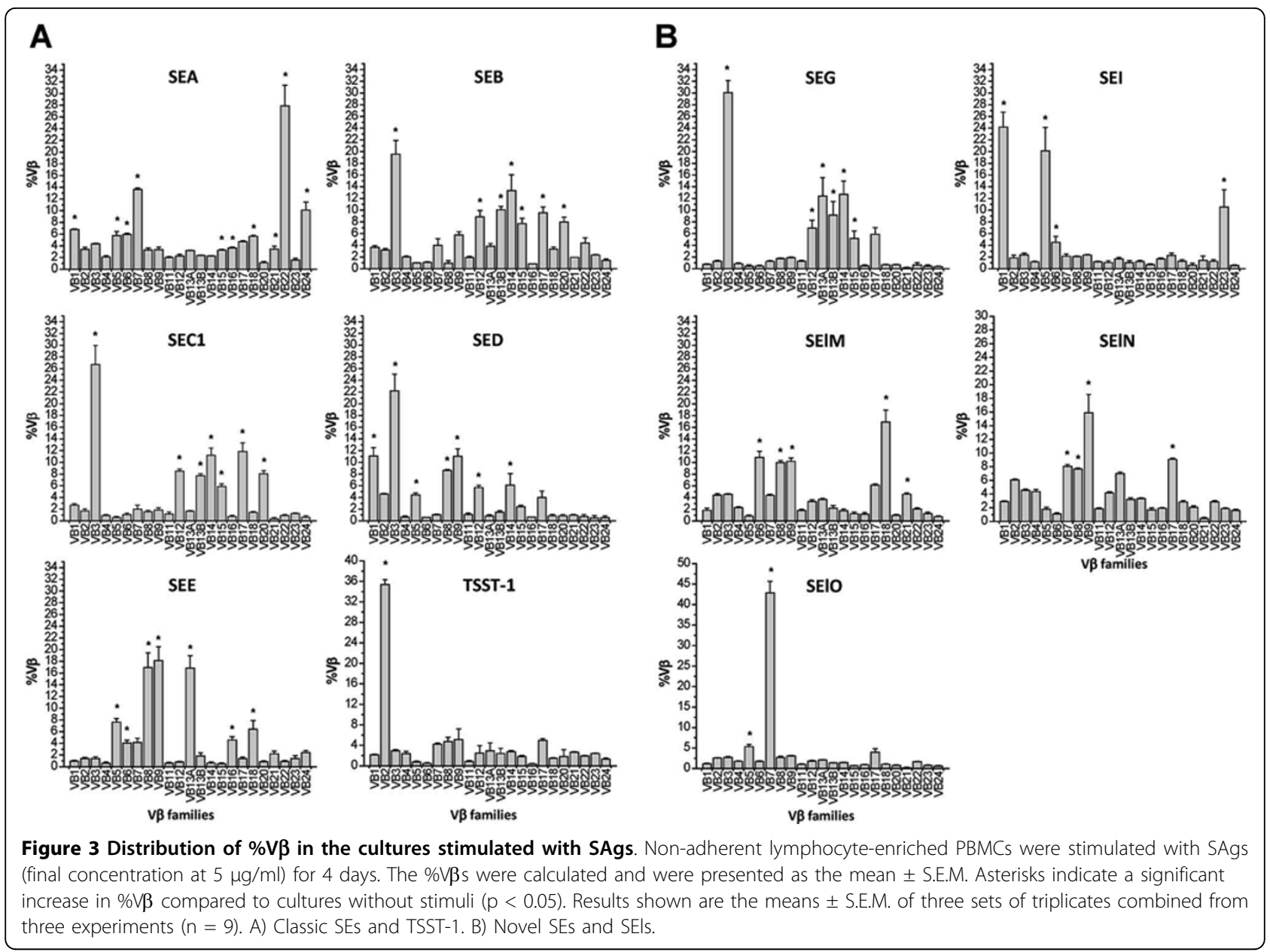

Table 4 Comparison of $V \beta$ specificity observed in this study with those in selected previous studies.

\begin{tabular}{|c|c|c|c|}
\hline SAgs & $V \beta$ specificity observed in this study & $\mathrm{V} \beta$ specificity observed in previous studiesa & References \\
\hline$\overline{S E A}$ & $V \beta 1,5,6,7,15,16,18,21,22,24$ & $V \beta 1,5,6,7,9,16,18,21$ & {$[24]$} \\
\hline SEB & $V \beta 3,12,13 B^{b}, 14,15,17,20$ & $V \beta 1,3,6,12,13.2,15,17,20$ & [11] \\
\hline SEC1 & $V \beta 3,12,13 B, 14,15,17,20$ & $V \beta 3,12,13.2,14,15,17,20$ & [12] \\
\hline SED & $V \beta 1,3,5,8,9,12,14$ & $V \beta 1,5,6,7,8,12$ & {$[7,25]$} \\
\hline SEE & $V \beta 5,6,8,9,13 A c, 16,18$ & $V \beta 5,6,8,13.1,18,21$ & {$[11,24]$} \\
\hline SEG & $V \beta 3,12,13 \mathrm{~A}, 13 \mathrm{~B}, 14,15$ & $V \beta 3,12,13,14$ & {$[26]$} \\
\hline SEI & $V \beta 1,5,6,23$ & $V \beta 1,5,6,23$ & [26] \\
\hline SEIM & $V \beta 6,8,9,18,21$ & $V \beta 6,8,9,18,21$ & [26] \\
\hline SEIN & $V \beta 7,8,9,17$ & $\vee \beta 9$ & [26] \\
\hline SEIO & $V \beta 5,7$ & $V \beta 5,7,22$ & [26] \\
\hline TSST-1 & $\vee \beta 2$ & $\vee \beta 2$ & [11] \\
\hline
\end{tabular}

${ }^{a} \mathrm{~V} \beta$ specificities were results from previous studies using semi-quantitative PCR or FACS methods.

${ }^{\mathrm{b}} \mathrm{V} \beta 13 \mathrm{~B}$ corresponds to $\mathrm{V} \beta 13.2$ in previous studies.

${ }^{\mathrm{C}} \mathrm{V} \beta 13 \mathrm{~A}$ corresponds to $\mathrm{V} \beta 13.1$ in previous studies. 
of $\mathrm{V} \beta$ subgroups and revealed that 36 out of 49 functional V $\beta$ subgroup genes were amplified. It suggests that primers used in this study were highly specific to targeted $\mathrm{V} \beta$ subgroup.

In this study, we used various SAgs showing similar and/or unique $V \beta$ specificities covering the entire repertoire of human V $\beta$ subgroups. The qRT-PCR showed that every $\mathrm{V} \beta$ subgroup was expanded in this study. As shown in Table 4, the V $\beta$ specificities of SAgs observed in this study was very similar to those described in previous studies with minor variation $[7,11,12,24-26]$. In this study, newly identified $V \beta$ specificities were observed for some SAgs such as SEA (VB15, 22, and

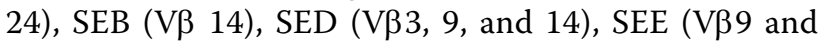
16), SEG (Vß15), and SEIN (Vß7, 8, and 17). Also, some $\mathrm{V} \beta$ previously reported specificities were not observed for some SAgs such as SEB (V $\beta 1$ and 6), SED (VB6 and 7), SEE (V $\beta 21)$, and SEIO (V $\beta 22)$. These discrepancies might be explained by the differences in the repose to SAgs among humans or differences in techniques (PCR, flow cytometry), or the lack of reagents at the time of previous studies. For example, the $\mathrm{V} \beta$ specificity of some SAgs in two previous studies was determined by semi-quantitative PCR using primers specific to $V \beta 1$ through V $\beta 20[11,12]$. This present study incorporated primers specific to $V \beta 21$ through $V \beta 24$. However, it is noteworthy that $V \beta$ subgroups most prominently expanded by each SAg observed in this study were identical to those observed in previous studies.

\section{Conclusion}

In this report, we developed an assay to quantify the expansion of human V $\beta$ subgroups using qRT-PCR. The specificity and efficiency of the method were evaluated by generating standard curves for each primer set. The validity of the method was assessed by analyzing the $V \beta$ specificity of various SAgs which combined, interact with $V \beta$ repertoires covering all known V $\beta$ subgroups. Our results demonstrate that the method established in this study is accurate, sensitive, and highly reproducible. This qRT-PCR method could also be used to characterize novel SAgs, to determine complete profiles of currently known SAgs, and to help understand the role of $\mathrm{T}$ cells bearing specific $\mathrm{V} \beta \mathrm{s}$ in certain diseases such as neoplastic expansion of large granular lymphocytes, $\mathrm{T}$ cell non-Hodgkin's lymphoma $[28,29]$ as well as some immune disorders associated with SAgs such as immunosuppression, Kawasaki disease, and atopy [30-32].

\section{Acknowledgements}

This work was supported by the grants from the National Institutes of Health Grants (P20 RR15587, P20 RR016454, and U54AI57141), the USDA NRI grant (2008-892) and the Idaho Agricultural Experimental Station.

\section{Author details}

${ }^{1}$ Department of Microbiology, Molecular Biology and Biochemistry, University of Idaho, Moscow, ID 83844, USA. ²Department of Veterinary Medicine, Washington State University, Pullman, WA 99164, USA. ${ }^{3}$ Jenomic, Inc, Carmel, CA, USA

\section{Authors' contributions}

KSS developed the basic assay and performed most experiments including cloning, protein purification, cell preparation and stimulation, QRT-PCR, and data analysis. JYP helped to perform qRT-PCR and interpret data. DST provided some toxins and input into general experimental strategy. GAB assisted in experimental design and helped to interpret data and draft the manuscript. All authors read and approved the final manuscript.

\section{Competing interests}

The authors declare that they have no competing interests.

Received: 1 July 2009

Accepted: 13 January 2010 Published: 13 January 2010

\section{References}

1. Davis MM, Boniface JJ, Reich Z, Lyons D, Hampl J, Arden B, Chien Y: Ligand recognition by alpha beta T cell receptors. Annu Rev Immunol 1998, 16:523-544.

2. Rowen L, Koop BF, Hood L: The complete 685-kilobase DNA sequence of the human beta T cell receptor locus. Science 1996, 272:1755-1762.

3. Davis MM, Bjorkman PJ: T-cell antigen receptor genes and T-cell recognition. Nature 1988, 334:395-402.

4. Behlke MA, Spinella DG, Chou HS, Sha W, Hartl DL, Loh DY: T-cell receptor beta-chain expression: dependence on relatively few variable region genes. Science 1985, 229:566-570.

5. Marrack P, Kappler J: Positive selection of thymocytes bearing alpha beta T cell receptors. Curr Opin Immunol 1997, 9:250-255.

6. Garcia KC, Degano M, Stanfield RL, Brunmark A, Jackson MR, Peterson PA, Teyton L, Wilson IA: An alphabeta T cell receptor structure at $2.5 \mathrm{~A}$ and its orientation in the TCR-MHC complex. Science 1996, 274:209-219.

7. Seo KS, Bohach GA: Staphylcoccus aureus. Food microbiology: Fundamentals and Frontiers Washington, DC: ASM PressDoyle MM, Beucaht LR 2007, 493-518.

8. Lina G, Bohach GA, Nair SP, Hiramatsu K, Jouvin-Marche E, Mariuzza R: Standard nomenclature for the superantigens expressed by Staphylococcus. J Infect Dis 2004, 189:2334-2336.

9. Bohach GA: Staphylococcus aureus Exotoxins. Gram-Positive Pathogens Washington, DC: ASM PressFischetti VA, Novick RP, Ferretti JJ, Portnoy DA, Rood Jl 2006, 464-477.

10. Mooney NA, Ju L, Brick-Ghannam C, Charron DJ: Bacterial superantigen signaling via HLA class II on human B lymphocytes. Mol Immunol 1994, 31:675-681.

11. Choi YW, Kotzin B, Herron L, Callahan J, Marrack P, Kappler J: Interaction of Staphylococcus aureus toxin "superantigens" with human T cells. Proc Natl Acad Sci USA 1989, 86:8941-8945.

12. Deringer JR, Ely RJ, Stauffacher CV, Bohach GA: Subtype-specific interactions of type $C$ staphylococcal enterotoxins with the T-cell receptor. Mol Microbiol 1996, 22:523-534.

13. Pilch $\mathrm{H}$, Hohn $\mathrm{H}$, Freitag $\mathrm{K}$, Neukirch $\mathrm{C}$, Necker A, Haddad P, Tanner B, Knapstein PG, Maeurer MJ: Improved assessment of T-cell receptor (TCR) VB repertoire in clinical specimens: combination of TCR-CDR3 spectratyping with flow cytometry-based TCR VB frequency analysis. Clin Diagn Lab Immunol 2002, 9:257-266.

14. Bercovici N, Duffour MT, Agrawal S, Salcedo M, Abastado JP: New methods for assessing T-cell responses. Clin Diagn Lab Immunol 2000, 7:859-864

15. Walters $G$, Alexander SI: T cell receptor BV repertoires using real time PCR: a comparison of SYBR green and a dual-labelled HuTrec fluorescent probe. J Immunol Methods 2004, 294:43-52.

16. Ochsenreither S, Fusi A, Busse A, Nagorsen D, Schrama D, Becker J, Thiel E, Keilholz U: Relative quantification of TCR Vbeta-chain families by real time PCR for identification of clonal T-cell populations. J Transl Med 2008, 6:34.

17. Deringer JR, Ely RJ, Monday SR, Stauffacher CV, Bohach GA: Vbetadependent stimulation of bovine and human $T$ cells by host-specific staphylococcal enterotoxins. Infect Immun 1997, 65:4048-4054. 
18. Li H, Llera A, Tsuchiya D, Leder L, Ysern X, Schlievert PM, Karjalainen K, Mariuzza RA: Three-dimensional structure of the complex between a $T$ cell receptor beta chain and the superantigen staphylococcal enterotoxin B. Immunity 1998, 9:807-816.

19. Bohach GA, Schlievert PM: Detection of endotoxin by enhancement with toxic shock syndrome toxin-1 (TSST-1). Methods Enzymol 1988, 165:302-306.

20. Monday SR, Bohach GA: Use of multiplex PCR to detect classical and newly described pyrogenic toxin genes in staphylococcal isolates. J Clin Microbiol 1999, 37:3411-3414.

21. Arden B, Clark SP, Kabelitz D, Mak TW: Human T-cell receptor variable gene segment families. Immunogenetics 1995, 42:455-500.

22. Sambrook J, Fritsch EF, Maniatis T: Concentration of DNA Solution. Molecular Cloning: A Laboratory Manual New York: Cold Spring Harbor Laboratory PressNolan C 1989, Appendix C1.

23. Yin JL, Shackel NA, Zekry A, McGuinness PH, Richards C, Putten KV, McCaughan GW, Eris JM, Bishop GA: Real-time reverse transcriptasepolymerase chain reaction (RT-PCR) for measurement of cytokine and growth factor mRNA expression with fluorogenic probes or SYBR Green I. Immunol Cell Biol 2001, 79:213-221.

24. Lamphear JG, Mollick JA, Reda KB, Rich RR: Residues near the amino and carboxyl termini of staphylococcal enterotoxin $E$ independently mediate TCR V beta-specific interactions. J Immunol 1996, 156:2178-2185.

25. Kappler J, Kotzin B, Herron L, Gelfand EW, Bigler RD, Boylston A, Carrel S, Posnett DN, Choi Y, Marrack P: V beta-specific stimulation of human T cells by staphylococcal toxins. Science 1989, 244:811-813.

26. Jarraud S, Peyrat MA, Lim A, Tristan A, Bes M, Mougel C, Etienne J, Vandenesch F, Bonneville M, Lina G: egc, a highly prevalent operon of enterotoxin gene, forms a putative nursery of superantigens in Staphylococcus aureus. J Immunol 2001, 166:669-677.

27. Lefranc M, Lefranc G: The T cell receptor New York: Academic Press 2001.

28. Loughran TP Jr, Starkebaum G, Aprile JA: Rearrangement and expression of T-cell receptor genes in large granular lymphocyte leukemia. Blood 1988, 71:822-824.

29. Willenbrock K, Roers A, Seidl C, Wacker HH, Kuppers R, Hansmann ML: Analysis of T-cell subpopulations in T-cell non-Hodgkin's lymphoma of angioimmunoblastic lymphadenopathy with dysproteinemia type by single target gene amplification of $\mathrm{T}$ cell receptor- beta gene rearrangements. Am J Pathol 2001, 158:1851-1857.

30. Seo KS, Park JY, Davis WC, Fox LK, McGuire MA, Park YH, Bohach GA: Superantigen-mediated differentiation of bovine monocytes into dendritic cells. J Leukoc Biol 2009, 85(4):606-16.

31. Seo KS, Lee SU, Park YH, Davis WC, Fox LK, Bohach GA: Long-term staphylococcal enterotoxin $\mathrm{C} 1$ exposure induces soluble factor-mediated immunosuppression by bovine CD4+ and CD8+ T cells. Infect Immun 2007, 75:260-269.

32. Yarwood JM, Leung DY, Schlievert PM: Evidence for the involvement of bacterial superantigens in psoriasis, atopic dermatitis, and Kawasaki syndrome. FEMS Microbiol Lett 2000, 192:1-7.

doi:10.1186/1479-5876-8-2

Cite this article as: Seo et al:: A quantitative real time PCR method to analyze $\mathrm{T}$ cell receptor $\mathrm{V} \beta$ subgroup expansion by staphylococcal superantigens. Journal of Translational Medicine 2010 8:2.

\section{Submit your next manuscript to BioMed Central and take full advantage of:}

- Convenient online submission

- Thorough peer review

- No space constraints or color figure charges

- Immediate publication on acceptance

- Inclusion in PubMed, CAS, Scopus and Google Scholar

- Research which is freely available for redistribution

Submit your manuscript at www.biomedcentral.com/submit
Biomed Central 